\title{
PELATIHAN PEMBUATAN PUPUK ORGANIK CAIR BAGI KELOMPOK TANI DESA KARTAMA PEKANBARU
}

\author{
Rahmadini Syafri*, Rahmiwati Hilma, Hasmalina Nst, Prasetya \\ Program Studi Kimia, Fakultas MIPA dan Kesehatan, \\ Universitas Muhammadiyah Riau. \\ *Email: rahmadini_syafri@yahoo.com
}

\begin{abstract}
Abstrak
Berbagai macam bentuk usaha untuk mencukupi perekonomian keluarga telah dilakukan masyarakat khususnya Desa Kartama. Upaya yang mereka tekuni tentunya harus dapat menghasilkan peningkatan ekonomi keluarga. Pertanian sayur mayur, ubi kayu dan peternakan merupakan salah satu usaha yang dilakukan oleh sebagian besar masyarakat Desa Kartama hingga saat ini.Usaha ini tentu sangat menguntungkan jika bisa dikelola dengan baik. Namun, terdapat permasalahan yang timbul dalam usaha pertanian sayur, perkebunan dan peternakan bagi sebagian masyarakat Desa Kartama. Permasalahan yang terjadi saat ini yaitu mahalnya harga pupuk komersil (kimia) yang dibutuhkan untuk sektor pertanian serta limbah peternakan baik urin maupun feses ternak yang dapat mencemari lingkungan. Untuk itu melalui program pengabdian kepada masyarakat ini kami memberikan ide kepada warga setempat yang memiliki perkebunan seperti sayur mayur, umbi-umbian untuk membuat pupuk sendiri dari bahan organik agar dapat mengurangi biaya perkebunan warga, dikarenakan untuk membuat pupuk organik cair tersebut tidak memakan banyak biaya karena bahan dasarnya diperoleh dari limbah rumah tangga seperti sisa buah-buahan dan sayur-sayuran. Disamping itu limbah dari peternakan juga dapat dimanfaatkan sebagai bahan dalam pembuatan pupuk organik cair.
\end{abstract}

Kata kunci: pupuk organik cair, limbah rumah tangga, urin sapi

\section{PENDAHULUAN}

Sejalan dengan meningkatnya kegiatan pembangunan di kota Pekanbaru menyebabkan meningkatnya kegiatan pelayanan kependudukan di segala bidang yang tentunya harus diikuti dengan penyediaan fasilitas oleh Pemerintah Kota Pekanbaru. Untuk memenuhi tuntutan masyarakat tersebut dan untuk lebih dekatnya jenjang birokrasi di kota Pekanbaru, maka berdasarkan Peraturan Daerah Kota Pekanbaru nomor: 3 tahun 2003, tentang pembentukan kecamatan baru di kota Pekanbaru, yaitu: Kecamatan Marpoyan Damai,
Kecamatan Tenayan Raya, Kecamatan Payung Sekaki, dan Kecamatan Rumbai Pesisir. Di Kecamatan Marpoyan Damai dibagi 5 (lima) kelurahan, yakni: Kelurahan I Desa Maharatu (Kartama), Kelurahan / Desa Sidomulyo Timur, Kelurahan / Desa Wonorejo, Kelurahan/Desa Tangkerang Barat, Kelurahan/Desa Tangkerang Tengah. Berdasarkan Peraturan Daerah Kota Pekanbaru Nomor 4 Tahun 2003. Tanggal 23 Desember 2003 diresmikan Kelurahan Maharatu/Kartama dengan 19 (sembilan belas) Rukun Warga (RW) dan 74 (tujuh puluh empat) Rukun Tetangga (RT). Luas Desa Kartama 
$16.982 \mathrm{~m} 2$, dengan batas-batas wilayah sebagai berikut:

- Sebelah utara berbatasan dengan Kelurahan Sidomulyo.

- Sebelah selatan dengan Desa Kubang Raya Kabupaten Kampar

- Sebelah timur berbatasan dengan Kelurahan Simpang Tiga

- Sebelah barat berbatasan dengan Kelurahan Sidomulyo Timur.

Kondisi wilayah ini merupakan dataran rendah yang relatif datar, yang terdapat perumahan, lahan pertanian dan perkebunan, peternakan, perkantoran dan sekolah. Masyarakatnya yang heterogen baik secara sosial dan ekonomi tercermin dari berbagai suku yang tinggal di wilayah ini antara lain, suku Jawa, Melayu, Batak, dan Minang dan adanya berbagai macam profesi dan usaha. Berbagai macam bentuk usaha untuk mencukupi perekonomian keluarga telah dilakukan masyarakat khususnya Desa Kartama. Upaya yang mereka tekuni tentunya harus dapat menghasilkan peningkatan ekonomi keluarga. Pertanian sayur mayur, ubi kayu dan peternakan merupakan salah satu usaha yang dilakukan oleh sebagian masyarakat Desa Kartama hingga saat ini. Usaha ini tentu sangat menguntungkan jika bisa dikelola dengan baik. Namun, terdapat permasalahan yang timbul dalam usaha pertanian sayur, perkebunan dan peternakan bagi sebagian masyarakat Desa Kartama. Permasalahan yang terjadi saat ini yaitu mahalnya harga pupuk komersil (kimia) yang dibutuhkan untuk sektor pertanian serta limbah peternakan baik urin maupun feses ternak yang dapat mencemari lingkungan.
Untuk itu melalui program pengabdian kepada masyarakat ini kami memberikan ide kepada warga setempat yang memiliki perkebunan seperti sayur mayur, umbi-umbian untuk membuat pupuk sendiri dari bahan organik agar dapat mengurangi biaya perkebunan warga, dikarenakan untuk membuat pupuk organik cair tersebut tidak memakan banyak biaya karena bahan dasarnya diperoleh dari limbah rumah tangga seperti sisa buahbuahan dan sayur-sayuran. Disamping itu limbah dari peternakan juga dapat dimanfaatkan sebagai alternatif dalam pembuatan pupuk organik cair. Salah satu peternakan yang banyak dikenal adalah peternakan sapi. Usaha peternakan sapi dengan skala lebih dari 20 ekor dan relatif terlokalisasi akan menimbulkan pencemaran lingkungan. Satu ekor sapi dengan bobot 400-500 kg dapat menghasilkan limbah padat dan cair sebesar 27, 5-30 g/ekor/hari (Martinsari, dkk, 2010). Data yang diperoleh dari Badan Pusat Statistik (BPS) Provinsi Riau tahun 2013, jumlah populasi ternak sapi mencapai 175.679 ekor1. Lingga menyatakan bahwa jumlah populasi yang tinggi ini akan menyebabkan limbah yang terhasil juga semakin tinggi, sedangkan pengelolaan limbah cair peternakan itu sendiri masih sangat kurang. Implikasinya kondisi ini akan berdampak negatif terhadap lingkungan seperti pencemaran air dan udara serta sumber penyakit. Padahal dari segi kandungan unsur haranya, pupuk kandang cair dari urin sapi ini memiliki kandungan hara yang lebih tinggi dibandingkan kotoran padatnya2 
Saat ini penggunaan pupuk anorganik di kalangan petani di Desa Kartama masih cukup tinggi. Kebutuhan pupuk untuk pertanian semakin banyak, namun tidak seimbang dengan produksi pupuk dan mahalnya harga pupuk. Handayani, dkk menyatakan penggunaan pupuk anorganik yang berlebihan dalam jangka waktu lama justru akan merugikan karena dapat merusak lingkungan seperti struktur tanah menjadi keras dan mikroorganisme tanah semakin berkurang yang berakibat pada menurunnya produktivitas tanah3. Dalam menanggapi hal tersebut, melalui program pengabdian masyarakat ini teknologi alternatif akan dilakukan dengan memanfaatkan limbah rumah tangga maupun pertanian dan perkebunan untuk memproduksi pupuk organik yang ramah lingkungan. Pupuk organik merupakan hasil fermentasi atau dekomposisi dari bahan organik seperti tanaman, hewan atau limbah organik lainnya4 (Indriani, 2002).

Pupuk organik berdasarkan bentuknya dibedakan menjadi dua macam yaitu pupuk organik padat dan pupuk organik cair5 (Hadisuwito, 2012). Pupuk organik cair memiliki kelebihan dibandingkan dengan pupuk padat yaitu unsur hara yang dikandung lebih cepat tersedia dan mudah diserap akar tanaman. Sumber bahan baku pupuk organik tersedia dengan jumlah yang melimpah terutama dalam bentuk limbah, yaitu limbah rumah tangga, limbah industri, limbah peternakan dan lainnya6 (Nasarudin dan Rosmawati, 2009).
Namun pengetahuan masyarakat Desa Kartama tentang hal ini masih sangat minim. Untuk itu, perlu dilakukan sosialisasi tentang cara pembuatan pupuk organik cair dari bahan limbah ternak dan limbah rumah tangga yang terdapat di kawasan lokasi mitra, sebagai usaha untuk mengurangi biaya operasional dan konsumsi pupuk pabrikan dalam pertanian dan perkebunan warga juga perlu disosialisasikan.

\section{METODE PENGABDIAN}

Penyelesaian masalah terhadap kondisi dan situasi mitra dilakukan dalam tahapan-tahapan berikut:

1. Desa/Lurah akan memberikan 20 orang kader kelompok Kelompok Tani nya untuk mengikuti pelatihan. Pembentukan kader ini akan memudahkan dalam transfer informasi materi ke masyarakat setempat.

2. Sosialisasi dan penyampaian pengembangan Ipteks dalam pemanfaatan limbah perkebunan, peternakan dan rumah tangga yang bernilai ekonomi untuk diolah menjadi pupuk organik cair.

3. Pemberian pelatihan ini meliputi pembuatan pupuk cair organik dari limbah kulit buah-buahan, sampel yang diambil adalah kulit buah nenas dan nangka serta limbah ternak sapi, limbah rumah tangga dan organik lainnya di Desa Kartama secara fermentasi sebagai alternatif pupuk pabrikan.

4. Pelatihan ini dilengkapi dengan sarana dan prasarana serta peralatan yang menunjang dan 
mekanisme prosedur kerja dari pembuatan pupuk organik cair.

5. Partisipasi Mitra dalam pelatihan ini lebih ditekankan kepada peningkatan keterampilan dan minat masyarakat dalam memanfaatkan limbah-limbah yang ada di lingkungan sekitar sehingga menjadi produk yang bernilai ekonomi melalui pembuatan pupuk organik cair dengan demikian dapat meningkatkan perekonomian keluarga.

6. Evaluasi pelaksanaan program dan pemantauan program yang berkelanjutan.

\section{Prosedur Kerja}

1. Persiapan Alat dan Bahan

Adapun peralatan yang digunakan dalam fermentasi pupuk organik cair adalah bioreaktor, pengaduk, selang, lakban, botol aqua kosong, sarung tangan, dan tisu. Sedangkan peralatan yang digunakan dalam persiapan bahan sampel adalah pisau, telenan, lesung penumbuk, blender, ember/baskom dan jirigen.

Bahan yang digunakan dalam proses pembuatan pupuk organik cair adalah limbah kulit, mahkota, dan bonggol nanas, limbah jerami/kulit nangka, urin sapi, EM-4 (Effective Microorganism-4), gula pasir (molasses), dan air suling.

2. Populasi dan Persiapan Bahan POC

Sampel dalam penelitian ini adalah limbah nenas dan nangka yang diambil dari pabrik industri keripik nenas dan nangka yang ada di Desa Kualu Nenas, Jalan Raya Pekanbaru-Bangkinang. Limbah nenas dan nangka ini terlebih dahulu di blender sampai halus (ditambahkan air suling untuk proses penghancuran). Sedangkan limbah cair urin sapi dari peternakan sapi di Pekanbaru. Masing-masing sampel terlebih dahulu disaring untuk membuang padatan dan benda asing yang ikut terlarut dan kemudian dicampurkan untuk proses fermentasi lebih lanjut.
3. Pembuatan Tetes Tebu (molasses)

Panaskan $800 \mathrm{ml}$ air didalam panci hingga medidih dan masukkan 800 g gula. Diaduk sampai gula merah larut kemudian didinginkan, disaring dan dimasukkan kedalam botol7.

\section{Aktivasi EM4 (Munawaroh, 2013)}

EM4 yang masih dalam keadaan tidur (dormant) diaktifkan dengan memberikan makanan dan air. Pengaktifan dilakukan dengan menambahan air dan air gula (molasses) dengan perbandingan 100 $\mathrm{ml} \mathrm{EM} 4+100 \mathrm{ml}$ air gula (molasses) + $2000 \mathrm{ml}$ air (konsentrasi EM4 5\%). Kemudian difermentasi selama 5 hari pada suhu ruang8.

\section{Proses Fermentasi Pupuk Organik Cair}

Pada pelatihan ini kami hanya akan mengambil satu komposisi saja untuk proses fermentasi pupuk organik cair tersebut yaitu komposisi bioreaktor yang ke-2 (POC 2), dengan jumlah komposisi limbah nenas dan nangka cair 7.5 L, penambahan urin sapi $2.5 \mathrm{~L}$, EM4 aktif $1 \mathrm{~L}$, dan aditif tetes tebu $1.5 \mathrm{~L}$.

\section{HASIL DAN PEMBAHASAN}

Kegiatan yang dilakukan meliputi Sosialisasi \& Demonstrasi 
ISSN : 2550-0198

Pembuatan Pupuk Organik Cair Mandiri menggunakan limbah kulit nenas dan nangka serta urin sapi dengan penambahan aktivator EM4 dan aditif tetes tebu (molasses).

Hasil kegiatan Pelatihan Pembuatan Pupuk Organik Cair dari mulai sosialisasi, pelatihan, penerapan dan pendampingan, berdasarkan tanya jawab langsung terlihat dalam tabel berikut:

Tabel 1 Hasil Kegiatan pelatihan pembuatan pupuk organik cair

\begin{tabular}{|c|c|c|}
\hline No & Kegiatan & Indikator \\
\hline 1 & Penyuluhan & $\begin{array}{l}\text { Dihadiri oleh } 18 \\
\text { peserta }\end{array}$ \\
\hline 2 & $\begin{array}{l}\text { Sosialisasi \& } \\
\text { peningkatan } \\
\text { pemahaman } \\
\text { masyarakat dalam } \\
\text { memanfaatkan } \\
\text { limbah atau } \\
\text { sampah rumah } \\
\text { tangga maupun } \\
\text { perkebunan serta } \\
\text { peternakan } \\
\text { menjadi pupuk } \\
\text { organik cair }\end{array}$ & $\begin{array}{l}\text { Bertambahnya } \\
\text { pengetahuan } \\
\text { peserta pelatihan } \\
\text { tentang } \\
\text { pembuatan pupuk } \\
\text { organik cair } \\
\text { mandiri dari } \\
\text { bahan } \\
\text { limbah/sampah }\end{array}$ \\
\hline 3 & $\begin{array}{l}\text { Pembuatan Tetes } \\
\text { tebu (molasses) }\end{array}$ & $\begin{array}{l}\text { Bertambahnya } \\
\text { bertambah } \\
\text { pengetahuan } \\
\text { peserta pelatihan } \\
\text { tentang } \\
\text { pembuatan } \\
\text { molasses sebagai } \\
\text { sumber makanan } \\
\text { bakteri EM4 }\end{array}$ \\
\hline 4 & $\begin{array}{l}\text { Pembuatan } \\
\text { larutan EM4 aktif } \\
5 \%\end{array}$ & $\begin{array}{l}\text { Bertambah } \\
\text { pengetahuan } \\
\text { peserta pelatihan } \\
\text { tentang } \\
\text { mengaktifasi } \\
\text { EM4 dengan }\end{array}$ \\
\hline
\end{tabular}

konsentrasi $5 \%$

$5 \quad$ Pembuatan bubur Bertambah

kulit nanas

pengetahuan

peserta pelatihan

tentang manfaat

kulit nenas

sebagai bahan

baku pembuatan

pupuk organic

cair

6 Pembuatan bubur Bertambah kulit nangka pengetahuan peserta pelatihan tentang manfaat kulit nangka sebagai bahan baku pembuatan pupuk organik cair

7 Pencampuran

Bertambah semua bahan pengetahuan pembuatan pupuk ke dalam Bioreaktor peserta pelatihan tentang proses fermentasi dalam bioreaktor pada pembuatan pupuk organik cair

8 Pemanfaatan Kulit nenas, kulit produk nangka dan urin sapi dapat diolah menjadi pupuk organik cair yang memiliki kandungan unsur hara makro dan mikro sesuai standar Permentan 2009

Dari hasil evaluasi tentang penyuluhan dan pelatihan pembuatan pupuk organik cair mandiri dari 
ISSN : 2550-0198

limbah/sampah rumah tangga, perkebunan dan peternakan terhadap tingkat pengetahuan dan keterampilan para peserta, umumnya mengalami peningkatan. Dari hasil tersebut menunjukkan bahwa kegiatan pengabdian kepada masyarakat ini berhasil.

\section{SIMPULAN}

Dari pelaksanaan kegiatan dapat ditarik kesimpulan yaitu kegiatan pemeriksaan darah gratis, mendapatkan tanggapan dan partisipasi yang sangat besar dari masyarakat, khususnya warga di Desa Kartama, Kec. Marpoyan Damai, Pekanbaru. Kegiatan pelatihan pembuatan pupuk organik cair mandiri dengan memanfaatkan limbah atau sampah mendapatkan tanggapan yang sangat positif dari masyarakat, beberapa peserta merasakan hasil pengetahuan yang diperoleh sangat membantu untuk mengurangi biaya pembelian pupuk sekaligus dapat dikembangkan menjadi usaha rumah tangga. Kandungan hara makro dan mikro yang dihasilkan pupuk organik cair ini berkualitas tinggi sesuai dengan standar baku mutu pupuk organik cair Permentan No. 28/Permentan/OT140/2/2009.

Dengan dikembangkannya manfaat limbah/sampah rumah tangga, perkebunan dan peternakan menjadi pupuk organik cair, secara tidak langsung akan dapat melestarikan lingkungan hidup yang ada disekitarnya dan meningkatkan perekonomian keluarga apabila dikembangkan menjadi wirausaha.

\section{DAFTAR PUSTAKA}

[1] BPS Provinsi Riau. Jumlah Ternak menurut Jenis dan Kabupaten/Kota. Pekanbaru. 2013.

[2] Lingga, P. Nutrisi Organik dari Hasil Fermentasi. Pupuk Buatan Mengandung Nutrisi Tinggi. Yogyakarta. 1999.

[3] Handayani, S.H., Yunus, A., \& Susilowati, A. Uji Kualitas Pupuk Organik Cair dari Berbagai Macam Mikroorganisme Lokal (MOL). Jurnal Biosains Pascasarjana. Universitas Negeri Semarang : Semarang. 2015

[4] Ardiningtyas, T. R. Pengaruh Penggunaan Effective Microorganism 4 (Em4) dan Molase Terhadap Kualitas Kompos dalam Pengomposan Sampah Organik RSUD dr. R. Soetrasno Rembang. Skripsi. Universitas Negeri Semarang: Semarang. 2013. 